Halyna Shchuka,

Doctor of Sciences (Pedagogical), Professor, Ferenc Rakoki II Transcarpathian Hungarian College of Higher Education, 6, Kashuto str., Berehove, 90200, Ukraine, ORCID: 0000-0003-4368-5081

\title{
«TOURISM-PHOBIA» IN BEREHOVE: CONFLICT POTENTIAL AND REASON SEARCHING
}

The article deals with the problems of tourism development in the Transcarpathian town of Berehove, caused by the Tourism-phobia of residents. It has been found that the aversion of residents to travellers can be related to exceeding the boundaries of physical, environmental, social and other opportunities of the territory and local communities, resulting in exacerbation of all existing problems. It is determined that tourism in Berehove can be described as tourism in urban areas. It has been proved that a significant number of the town's residents do not see the prospects for tourism development for fear of price increases; deterioration of the ecological state of the environment; local population conflicts with tourists; changes in the usual way of life; increasing competition for resources. The factors that act as additional stimuli for tourismphobia are distinguished: independence of travel; a limited number of services in recreation complexes; the sophistication and economy of the modern tourist against the background of the local tourism business unchanging philosophy; completion of the destination lifecycle; lack of seasonality; the age of a typical tourist.

Keywords: overtourism, tourismphobia, urban tourism, tourism in urban areas.

Relevance of research topic. The tourism industry continues to show extremely high rates of development. Zurab Pololikashvili, UNWTO Secretary-General, noted that the number of tourists on the planet in 2018 increased by $5 \%$, reaching 1.4 billion people and this result was obtained two years earlier than predicted (UNWTO, 2019).

It is natural that with such rates of development, tourism is a catalyst for economic progress and has a significant impact overall area of life. For a long time, almost all countries, cities and regions have made every effort to increase the number of tourists in their territory. Currently, those who have emerged as leaders face challenges such as overtourism and tourism-phobia. 
Herewith tourism is also observed in the areas that cannot boast a high level of tourism development. Thus, in Berehove (Transcarpathia), conflicts between tourists and locals occur periodically. Using networks and electronic publications they are widely publicized and regarded as the iceberg tip, and the unwillingness to develop tourism is at the heart of which, because there is a negative effect on the town.

Formulation of the problem. Transcarpathia is traditionally considered as a region rich in tourist resources, therefore, the tourism is always defined as a toppriority goal in the Regional Strategy of Development of the Transcarpathian region. According to the results of the tourist season 2019, the town of Berehove was among the regional leaders in the number of visitors and the volume of the tourist tax. Moreover, the town does not position itself as a tourist and does not take appropriate steps towards the development of urban tourism.

Analysis of recent researches and publications. Tourismphobia is a rather new and ambiguous phenomenon that has attracted attention both foreign (F. HigginsDesbiolles, S. Carnicelli, Ch. Krolikowski， G. Wijesinghe， K. Boluk，C. Milano, J. M. Cheer, M. Novelli, M. Martins), and domestic (A. Okhrimenko, N. Opanasyuk) researchers. Most of them associate it with overtourism and first of all, consider ways of solving the current situation. However, the inhabitants' Tourismphobia of the territories with a small tourist flow remains out of researchers' attention. Partially, S. Peidzha, S. Low, G. Ashworth, A. Kovalchyk, I. Pisarevskyy, and others have worked on this issue, exploring the essence of such a phenomenon as urban tourism. At present, we do not know any work of our compatriots on the Tourismphobia problem.

In this regard, the purpose of the publication was determined: to determine the level of Tourismphobia among the residents of Berehove and to identify the factors that caused this situation.

Presenting the main material. Discussions continue around the definition of «tourism-phobia», «overtourism», «city tourism» concepts.

Within the scope of this study the overtourism is defined as an excessive increase in the number of visitors, which leads to an overcrowding of the territory, causing the local population to suffer from the effects of time and season peaks, causing constant changes in their lifestyle, complicate access to amenities and impair the overall well-being (Claudio Milano, Marina Novelli, Joseph M. Cheer, 2019). To this environmental pollution, damage to cultural heritage, vulgarization of national culture or, even, loss of identity, exacerbation of criminogenic situation, increased sense of underperformance due to economic inequality with tourists, infrastructure problems, etc. should be added.

Overtourism is a complex problem that arises when tourism at a certain time and place begins to exceed the boundaries of the physical, ecological, social, psychological and political capacities of the territory and local communities (Freya 
Higgins-Desbiolles, Sandro Carnicelli, Chris Krolikowski, Gayathri Wijesinghe, Karla Boluk, 2019). The result of overtourism is tourism-phobia, a phenomenon characterized by the negative attitude of the destination inhabitants to tourists. For the foregoing reasons, it is clear that saturation with tourists may occur even with minor tourist flows if they exceed the permissible limits. That is, theoretically, in Berehove there may be Tourismphobia due to overtourism. But to conclude, it is necessary to characterize the state of tourism in the town.

Analysing the results of foreign studies, we must recognize that overtourism is more typical for cities. Today, urban tourism as a separate component of the tourism industry is just beginning to develop its potential, and scholars are debating the essence of the terms «urban tourism» and «tourism in urban areas». We are impressed by the fact that the main difference lies in the emotional well-being of tourists in the city they visit, not in space (A. Kowalczyk, 2005). Hence, urban tourism is a visit to and development of knowledge of a city that is treated as a cultural heritage and regarded as an indivisible element of the tourist space. Tourism in urban areas combines all forms of tourism related to the resources and tourism infrastructure of urban areas (including leisure, business, cultural and entertaining, cultural and cognitive, religious, sport and shopping tourism).

Almost all tourists in the town of Berehove (except for transit ones) have arrived for health improvement on thermal mineral waters. However, it does not make it possible to classify the town as a centre of health and recreation tourism, as the provision of health-improving services is localized within two complexes «Sports Base «Transcarpathia» and LLC «Zhaivoronok - Pachirta».

The attractiveness of urban space for tourists focuses mainly on the presentation of space (according to D. McCannel's theory of the three components of the tourist attraction of the city: tourist attractions, locals and marketing) (Lucas P. Konzen, 2014).

Despite the availability of historical and cultural tourist resources such as the Roman Catholic Church of the Holy Cross Exaltation (XI c.), the Palace of Transylvanian Prince G. Bethlen (1629), the Reformed Church (1775), the Palace of Justice of the Royal Court (1909), the Master Casino (1913), the Twin Houses, the stone humpback bridge, etc. in Berehove they are not presented and considered as a tourist resource. The same situation is with traditional gastronomic festivals, wine cellars, Hungarian cuisine.

At the present stage of tourism development, much attention is paid to the environment in which the tourist comes across: marketing relations and the economy of impressions have actualized the importance of the atmosphere, the special spirit prevailing in the destination, and to which the traveller seeks to become familiar with. Therefore, the success of tourism development in a certain area depends entirely on its inhabitants and their attitude to visitors. 
To determine the presence of tourism-phobia, we interviewed 160 residents of Berehove at the age of 18 and older. Due to the multi-ethnic nature of the region, the questionnaire was offered in Ukrainian and Hungarian languages. $55 \%$ of respondents chose questionnaires in Ukrainian language. There were 15 Russian and 17 Roma among the respondents. Thus, the representativeness of the sample by national composition of the population was ensured. $65 \%$ of the respondents are men. The age structure of the respondents is the following (see Figure 1):

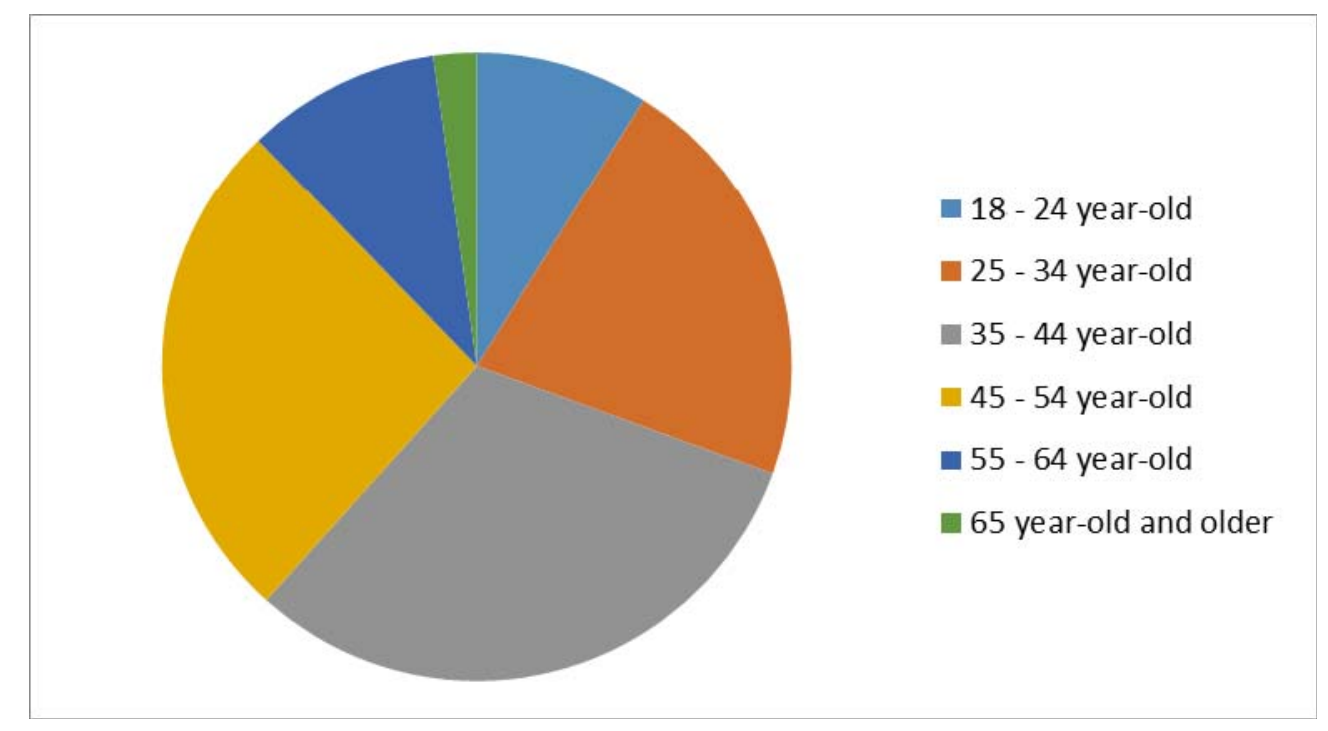

Fig. 1. The age structure of the respondents

The socio-professional status of the respondents is presented below (see Figure 2):

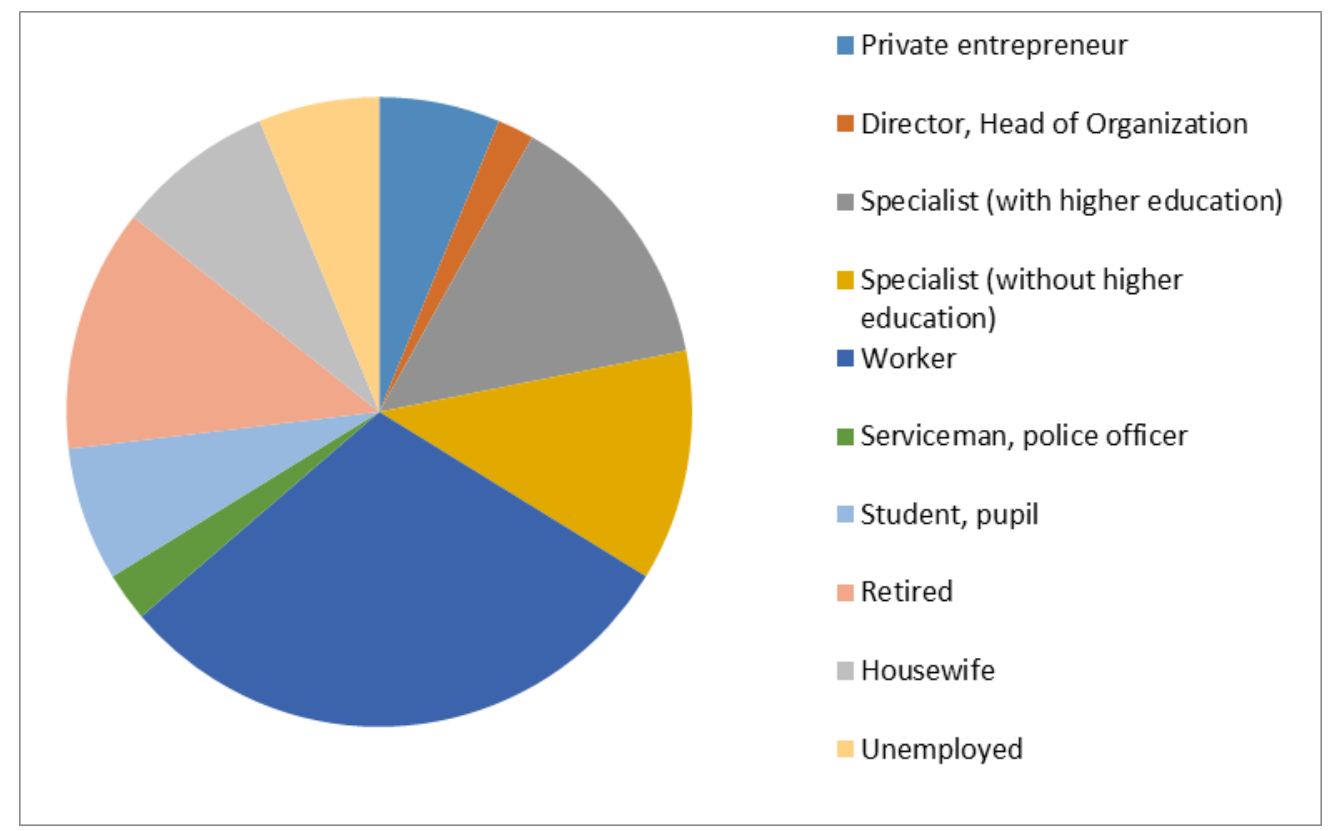

Fig. 1. The socio-professional status of the respondents 
Survey results. 112 people $(70 \%)$ believe that tourism is a promising direction of development for the town, 30 (19\%) have the opposite opinion, $18(11 \%)$ said that it is difficult for them to answer this question. Obviously, developing tourism in a town, where every fifth inhabitant does not see perspective in it, is quite problematic.

However, not seeing the prospects for tourism development in the town and being a tourism-phobian are different things. That is why let us look at this segment of respondents in more detail. Pessimistic sentiments about the town's tourism future are increasing with age: only one in ten under 45 has the following doubts, one in five after 45 , the second $(41.2 \%)$ after 55 , and all respondents over 65 .

They are scared of (in descending order):

- price increases;

- deterioration of the ecological state of the environment;

- local conflicts with tourists;

- changing the habitual lifestyle;

- increasing competition for resources (such as land, apartments).

Let us analyse the results obtained: Berehove still shows persistent irritation and negative attitude towards tourists.

Of course, there is an insufficient level of improvement of urban areas, a limited range of recreational services, a minimum number of leisure activities, etc., that with growth of population in the town increases intensity. A few more specific factors that may be detonators in this situation must be added:

1. Travel independence. A tourist does not contact the travel agency, finds accommodation in the private sector and therefore interacts more with the local population.

2. A limited number of services (complete absence of leisure organization) in the recreation facilities. Tourists have to entertain themselves but there are no opportunities.

3. The tourist has changed: he has become more demanding and economical. It is harder to work with him. But the philosophy of the tourist business and the level of service in the town have not changed in the last fifteen years.

4. Completion of destination lifecycle. A kind of euphoria, when everyone believed that tourism would work a miracle, is over. Life in the town has not been improved. Moreover, not everyone gets the profit, which causes the envy and frustration of others.

5. Lack of seasonality - year-round flow of tourists does not leave the town residents time to rest.

6. Typical tourist age and poor health - elderly sick people are less mobile, more conservative and conflicted.

Furthermore, some of the conflicts have an ethnic basis, because the majority of the town's inhabitants are Hungarians and most tourists come from Ukraine. And 
according to the survey among those who do not see the prospects for tourism development, $67 \%$ are Hungarians. However, let us turn to the conclusions of Marco Martins: actual hatred of tourists does not depend on their ethnicity or social status, religion, gender, sexual orientation. But xenophobia, racism, and other forms of radicalism can provoke and/or to be a triggering mechanism for growing of hostility and violence against newcomers (Marco Martins, 2018). It enables to speak about the creation of an artificial basis for Tourismphobia among the population of Berehove, Transcarpathian region.

Conclusion. It is established that overtourism can be traced in tourist destinations, even with relatively low tourist flows and cause Tourismphobia among the local population. Tourism in the town of Berehove is developing thanks to the available tourism resources, but it is not urban tourism (like visiting and development of knowledge about the city). It is determined that $18.8 \%$ of residents (mostly older people) do not consider tourism as a promising direction of the city development, foreseeing among the various negative consequences conflicts of the local population with leisure travellers. The factors that act as additional stimuli are distinguished: independence of travel; a limited number of services in recreation resorts; the sophistication and economy of the modern tourist against the background of the constant philosophy of the local tourist business; completion of destination lifecycle; lack of seasonality; the age of a typical tourist.

The scientific controversy over Tourismphobia has emerged recently and is rather limited. The reasons for Tourismphobia are heterogeneous, that indicates the complexity and the need to define different research parameters. The prospects for further research are to identify bilateral approaches to regulating tourism activities, taking into account not only the tourist's impressions but also the quality of local population life.

\section{REFERENCES}

1. Bilshe ne 152 tysiachi: Berehove ta Uzhhorod vtratyly $20 \%$ uhortsiv [More than 152,000: Beregovo and Uzhgorod lost $20 \%$ of Hungarians]. Mukachevo.net, from July 15, 2018. Retrieved from http://www.mukachevo.net/ua/news/view/366509. (accessed 05 March 2020) [in Ukrainian].

2. Claudio Milano, Marina Novelli \& Joseph M. Cheer. (2019). Overtourism and Tourismphobia : A Journey Through Four Decades of Tourism Development, Planning and Local Cncerns - Tourism Planning \& Development, 16 (4), 353-357. Retrieved from https://www.tandfonline.com/doi/full/10.1080/21568316.2019. 1599604. (accessed 05 March 2020) [in English]. 
3. Freya Higgins-Desbiolles, Sandro Carnicelli, Chris Krolikowski, Gayathri Wijesinghe \& Karla Boluk. (2019). Degrowing tourism: rethinking tourism - Journal of Sustainable Tourism, 27 (12), 1926-1944. Retrieved from https://doi.org/10.1080/09669582.2019.1601732. (accessed 05 March 2020). [in English].

4. Kowalczyk A. (2005). Nowe formy turystyki miejskiej - Prace i Studia Geograficzne, 35, 155-197. Retrieved from http://wgsr.uw.edu.pl/wgsr/wpcontent/uploads/2018/11/Kowalczyk_1.pdf. (accessed 05 March 2020) [in Polish].

5. Lucas P. Konzen. (2014). Tourist Representations and Public Space Regulation - International Journal for the Semiotics of Law, 27 (1), 135-160. Retrieved from https://link.springer.com/article/10.1007\%2Fs11196-013-9321-1. (accessed 05 March 2020) [in English].

6. Marco Martins. (2018). Tourism Planning and Tourismphobia: An Analysis of the Strategic Tourism Plan of Barcelona 2010-2015 - Journal of Tourism, Heritage \& Services Marketing, 4 (1), 3-7. Retrieved from https://mpra.ub.unimuenchen.de/88203/. (accessed 05 March 2020) [in English].

7. UNWTO tourism highlights: 2019 edition. (2019). Retrieved from https://www.e-unwto.org/doi/book/10.18111/9789284421152. (accessed 05 March 2020) [in English]. 